\title{
Development of IoT-Based Lighting Installation Practicum Module
}

\author{
Ahmad Mukhaidir Shidiq ${ }^{1}$, Purwito ${ }^{1}$ dan Ruslan ${ }^{1}$ \\ ${ }^{1}$ Electrical Engineering Department, Politeknik Negeri Ujung Pandang, \\ Jl. Perintis Kemerdekaan Km. 10 Tamalanrea, Makassar 90245, Indonesia \\ Email: stelkkhaidir@gmail.com
}

\begin{abstract}
With the advancement of technology today, there is known to be an innovation that is the internet of things where electronic devices can be monitored and controlled remotely. For this reason, the practicum module of internet of things-based lighting installation as a medium of learning for students. The workings of the tool will be made using the PZEM-004T sensor as a sensor reading the current voltage, power, and energy used and ESP-32 as an additional module on the Arduino Mega so that data reading voltage, current and power can be sent using the internet network to the smartphone. In the smartphone application, we can also control to extinguish or turn on the lights.
\end{abstract}

Keywords--Internet of things; Thingsboard; Arduino Mega; ESP-32; PZEM-004T; Relay; Smartphone

\section{Introduction}

Today, technology is evolving very rapidly. One example is the automation system of a device that can facilitate or provide comfort to humans. So that the activities or work done becomes easier. Automation systems were originally only used in the industrial world to drive machines automatically. But now all kinds of systems can be automated not only in the field of industry. Another example of technology that is currently developing is the process of automation in the home. This system is often heard as a smart home.

A smart home is a device that has a very sophisticated automation system for controlling lights and temperature, multimedia devices to monitor and turn on security systems connected to doors or windows and some other functions. Smart homes have several benefits such as providing better comfort, more guaranteed safety and security, and saving on electricity use. With the advancement of technology, especially in the field of telecommunications, it is undeniable that the use of the internet by the public is greatly increased and almost takes up to 24 hours. And now many technological devices that can be connected to the internet both electronic devices and computer tools and smartphones that everyone today must have. With these advances, there is an innovation where all these technological tools can be controlled remotely over the internet to be more efficient and save time. This is called the Internet of Things or IoT. Internet of Things enables any time connection, Any Things connection, and Any Place connection. The use of IoT can be applied to control several electronic devices in the house such as lights, automatic door locks and opening or closing automatic fences. Such controls can be done remotely using a smartphone device. The smartphone device is connected to the internet which as a bridge between the tool and the control system used. In the previous thesis reference, the system is in the form of a practicum module and works with the help of a manual. Therefore, the research conducted by the author is to add an internet of things system. In this internet of things system, the system works by controlling and monitoring lights and other devices making it easier for students to retrieve data and can compare data taken from sensors with data taken from measuring instruments. Based on the problems that occurred above, this thesis will aim to develop a practicum module of internet-based lighting installation of things. To make a smart home with the concept of the Internet of Things in the form of a practicum module requires software and hardware that is arranged with 
various functions as a system. The devices used are Node MCU and Arduino IDE.

\section{Research Methods}

This method of design and research is carried out with the following steps:

\section{A. Hardware Design}

\section{Mechanical Box Planning}

At the design box design stage of this tool, the author uses the SketchUp application to create a 3D design. This box size has dimensions with a length of $28.4 \mathrm{~cm}$, a width of $19.4 \mathrm{~cm}$ and a height of $9.1 \mathrm{~cm}$.

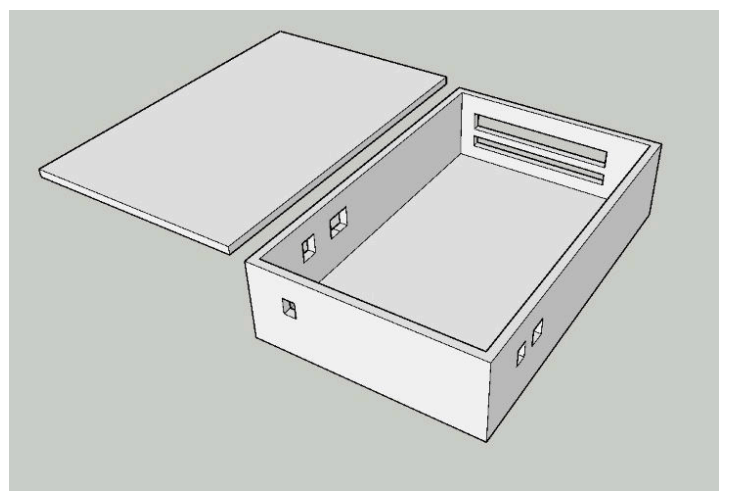

Figure 1. Interior Box Design

\section{Electronic Planning}

In this design, the author creates a diagram of the system's overall working block.

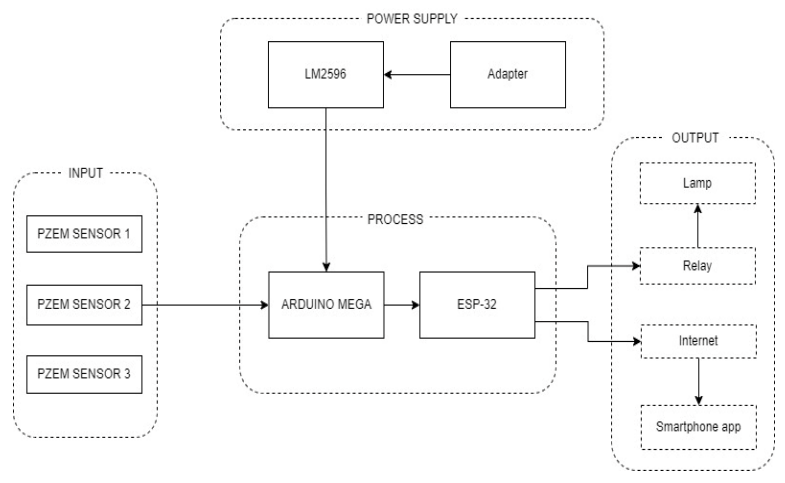

Figure 2. Electronic Design Block Diagram

The block diagram shows the Arduino and ESP32 as the controller center. The LM2586 serves as a voltage lowering of the adapter before supplying the voltage to the Arduino that works at a voltage of $5 \mathrm{~V}$. The PZEM004-T sensor will read the voltage, current and power in the practicum module and will be processed by ESP-32 so that voltage, current, and power readings can be sent to applications on the smartphone using an internet connection. In the smartphone application we can also control the lights that are in the first, second and third groups by pressing a button in the application so that the ESP32 receives commands from the smartphone, then the ESP-32 connected to the arduino will process the command, so that the relay can be active and turn on the lamp.

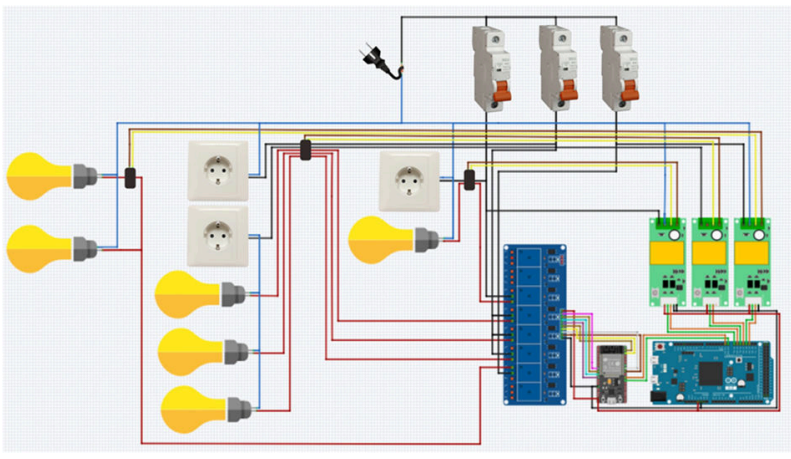

Figure 3. Overall Network

\section{PCB Planning}

Development of the Internet of Things (IoT) Based Lighting Installation Practicum Module, designed using Altium software.
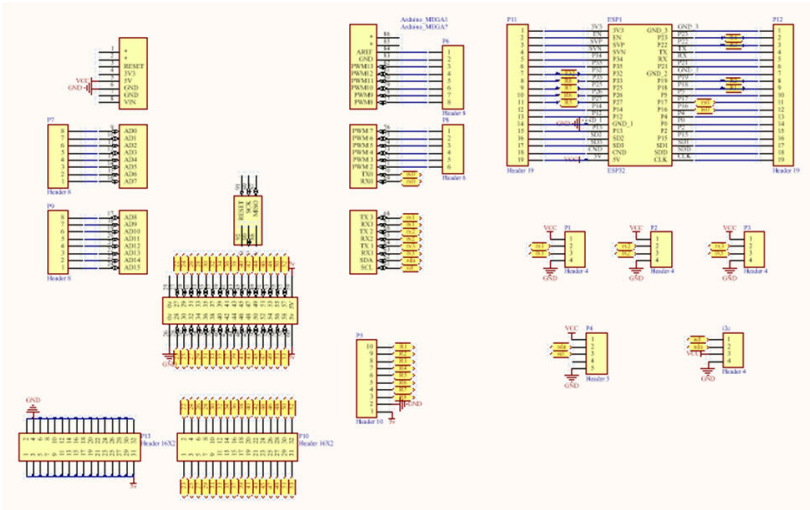

Figure 4. Schematic Series PCB Module Practicum Installation Lighting 


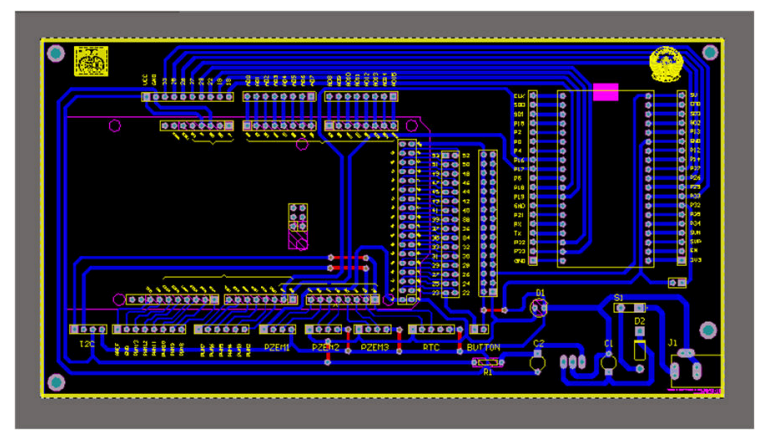

Figure 5. PCB Path Of Lighting Installation Practicum Module

\section{Software Design (Software)}

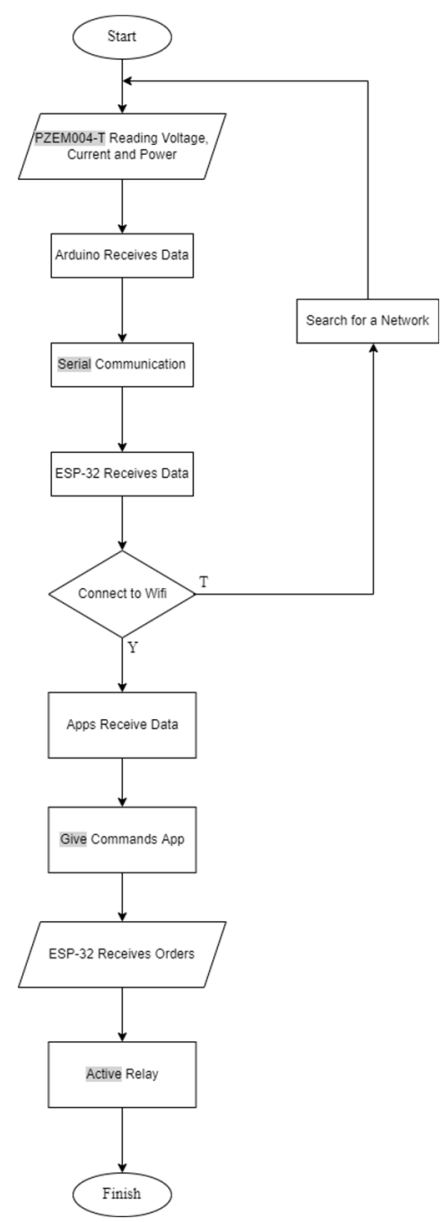

Figure 6. Flowchart System Control and Monitoring Lighting Installation Module

Flowchart in Figure 14 explains that when the system is working, PZEM will read the voltage, current, power and energy data and then send the data to Arduino. The data is received by the ESP-32 using serial communications between the Arduino Mega and ESP-
32. When the ESP-32 is connected to the network, the PZEM004-T sensor will send a reading of voltage, current, power and energy data to applications that have been made in the smartphone, this smartphone must be connected to the internet network in order to receive data or send data to the microcontroller.

Smartphones can also activate lights when given commands. When the smartphone gives a command, the microcontroller will read the command and process it, then the microcontroller that will provide active logic to the relay so that the active relay of lights connected to the relay can function.

\section{Results and Discussions}

\section{A. Design Results and Description of Tools}

The design results of the robot can be seen after going through several stages, namely the manufacture and assembly of boxes, the manufacture of electronic systems, and the creation of software / programs. 4.2 The Results of Box Manufacture and Assembly In the manufacture of mechanical boxes, first made the cutting of clear cliric material with a thickness of $3 \mathrm{~mm}$. Frames made of acrylic are then cut using a cutting machine. Frames that have been made next are assembled so that they appear in accordance with the design that has been designed.

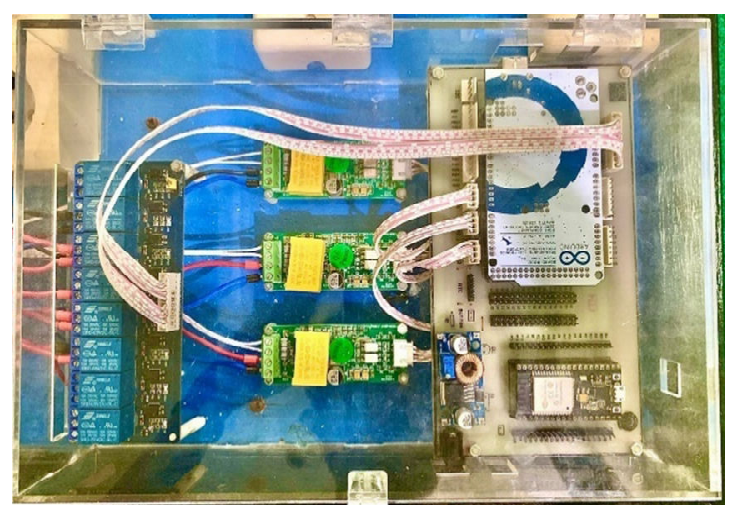

Figure 7. Assembly Results Appear Over Tools

\section{B. Electronic System Manufacturing Results}

The robotic electronic system is a board that connects the Arduino Mega, ESP-32, PZERM004-T sensor, module relay, step down, header pin, and dc jack 
pin. The board is made by attaching a path that has been made to the copper layer of the PCB by way of iron. The attached path is then soaked in a solution of $\mathrm{H}_{2} \mathrm{O}, \mathrm{H}_{2} \mathrm{O}_{2}$, and HCL until the unused copper layer is lost. Next, install the components in accordance with the schematic that has been designed. The designed device that has been made will then put in the raft with lighting installation modules. Here are the results of the assembly of the design tool in the lighting installation module as shown in Figure 8.

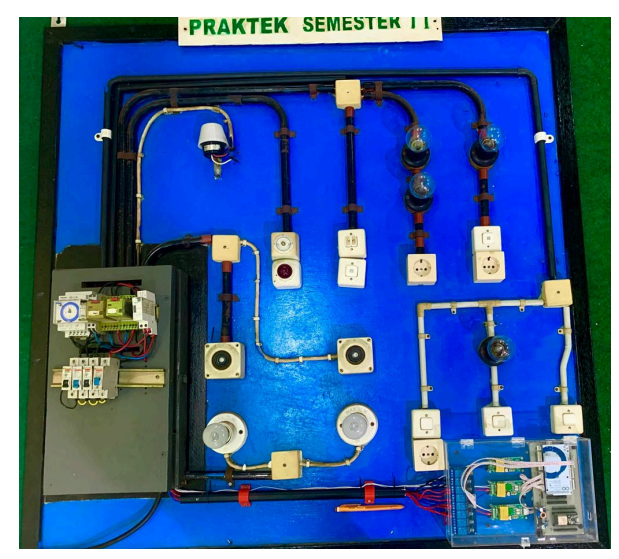

Figure 8. Assembly of Design Tools on Lighting Installation Module

\section{Software Creation Results}

There are several widgets that display widgets for relay control used to turn lights on or off, widgets that display voltage, current and power information in each group of Lighting Installation Modules and widgets that display voltage, current, power and energy usage graphs.

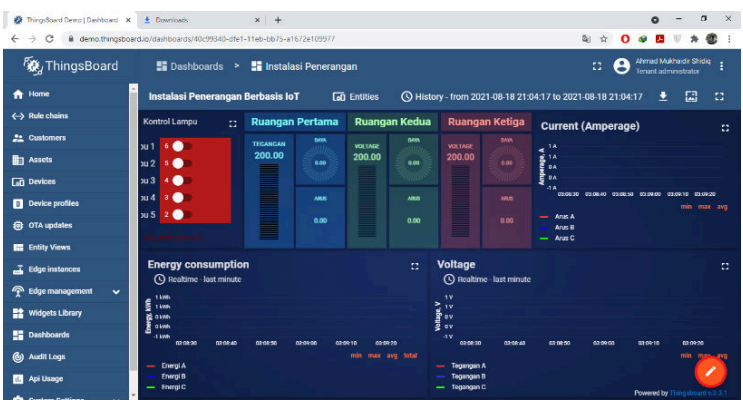

Figure 9. Results of Making Monitoring Software

\section{Testing on Hardware Modules}

The test was conducted by comparing the measurement results of the PZEM004-T sensor with the measuring instrument. This test is done by testing the error of each sensor and the total error of the tool. In the design of this tool there are three sensors connected to each load.

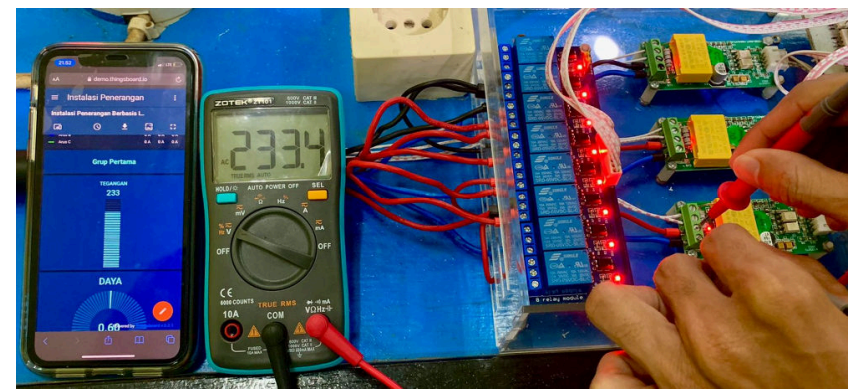

Figure 10. Comparison of Design Tools and Measuring Tools

To find out the magnitude of the deviation in the results of the design measuring instrument is done by comparing the results of the design measuring instrument itself with the results of the measurement with the standard measuring instrument with the following equations:

$$
\% \text { Error }=\frac{(\text { Standar instrument }- \text { Design instrumemt })}{\text { Standar } \text { instrument }} \times 100 \%
$$

Table 1 Comparison of Design Tools with Measuring Tools in the First Group

\begin{tabular}{|c|c|c|c|c|c|c|}
\hline \multirow{2}{*}{ Type of Load } & \multicolumn{2}{|c|}{ Design Tools } & \multicolumn{2}{|c|}{ Measuring Instrument } & Voltage & Current \\
\cline { 2 - 5 } & $\begin{array}{c}\text { Voltage } \\
\text { (Volt) }\end{array}$ & $\begin{array}{c}\text { Current } \\
\text { (Ampere) }\end{array}$ & $\begin{array}{c}\text { Voltage } \\
\text { (Volt) }\end{array}$ & $\begin{array}{c}\text { Current } \\
\text { (Ampere) }\end{array}$ & $\begin{array}{c}\text { Error } \\
(\%)\end{array}$ & $\begin{array}{c}\text { Error } \\
(\%)\end{array}$ \\
\hline No Burden & 233,2 & 0 & 233,9 & 0,03 & 0,3 & 1 \\
\hline Lamp & 232,3 & 0,12 & 233,2 & 0,13 & 0,4 & 7,6 \\
\hline Heater & 216 & 5,21 & 217 & 5,04 & 0,46 & 3,3 \\
\hline
\end{tabular}


Table 2 Comparison of Design Tools with Measuring Instruments in the Second Group

\begin{tabular}{|c|c|c|c|c|c|c|}
\hline \multirow[b]{2}{*}{ Type of Load } & \multicolumn{2}{|c|}{ Design Tools } & \multicolumn{2}{|c|}{ Measuring Instrument } & \multirow{2}{*}{$\begin{array}{c}\text { Voltage } \\
\text { Error } \\
(\%)\end{array}$} & \multirow{2}{*}{$\begin{array}{c}\text { Current } \\
\text { Error } \\
(\%)\end{array}$} \\
\hline & $\begin{array}{l}\text { Voltage } \\
\text { (Volt) }\end{array}$ & $\begin{array}{c}\text { Current } \\
\text { (Ampere) }\end{array}$ & $\begin{array}{l}\text { Voltage } \\
\text { (Volt) }\end{array}$ & $\begin{array}{l}\text { Current } \\
\text { (Ampere) }\end{array}$ & & \\
\hline No Burden & 233,2 & 0 & 233,1 & 0,04 & 0,04 & 1 \\
\hline 1 Lamp & 231,7 & 0,13 & 233,9 & 0,14 & 0,94 & 7,1 \\
\hline 2 Lamp & 231,7 & 0,21 & 232,2 & 0,2 & 0,21 & 5 \\
\hline 3 Lamp & 231,1 & 0,32 & 232,2 & 0,3 & 0,47 & 6,6 \\
\hline Iron & 227,6 & 1,4 & 228,9 & 1,35 & 0,56 & 3,7 \\
\hline Solder & 232,1 & 0,13 & 233 & 0,12 & 0,38 & 8,3 \\
\hline
\end{tabular}

Table 3 Comparison of Design Tools with Measuring Tools in The Third Group

\begin{tabular}{|c|c|c|c|c|c|c|}
\hline \multirow{2}{*}{ Type of Load } & \multicolumn{2}{|c|}{ Design Tools } & \multicolumn{2}{c|}{ Measuring Instrument } & Voltage & Current \\
\cline { 2 - 5 } & Voltage & Current & Voltage & Current & Error \\
(Volt) & (Ampere) & Error \\
$($ (Ampere) & $(\%)$ & $(\%)$ \\
\hline No Burden & 228,3 & 0 & 228,7 & 0,06 & 0,17 & 1 \\
\hline Lamp & 231,1 & 0,15 & 232,4 & 0,14 & 0,55 & 7,1 \\
\hline
\end{tabular}

Based on Table 1, Table 2 and Table 3 of the three tests of the tool can be concluded that the average total error for voltage measurement is $0.39 \%$ and the error for current measurement is $4.31 \%$. From the error data, recalibration is needed for current measurement because there are still high errors that occur.

\section{Conclusion}

The development of the Internet of Things (IoT) Based Lighting Installation Practicum Module was designed into module form, using Arduino mega microcontrollers and ESP-32 as controllers while relays connect electricity. Voltage, current, power and electrical energy are monitored through applications made from the things board platform. In this application can be done controlling lights remotely as long as the microcontroller and smartphone are connected to the internet network.

\section{Reference}

[1] Abidin, Z., "Smart Home Security and Monitoring Systems Online Using Mobile Devices". Journal of Computer Engineering Universitas Komputer Indonesia, Vol. 3, No. 2, pp.13-17. 2015.

[2] Adam, Jefri Lianda, and Dolly Handarly, "Internet of ThingsBased Remote Electrical Power Consumption Monitoring System". Journal of Engineering Technology. Vol. 4, No. 79. 2019. DOI: 10.31544. 2019.

[3] A. Furqon, A.B. Prasetijo, and E. D. Widianto, "Design An Electric Power Monitoring and Control system in Boarding Houses Using NodeMcu and Android-Based Firebase". Electron Science. Vol. 18, No. 2, pp. 93-104. 2019.

[4] Budiawan, M. S., "Electric Current Load Control System". Makassar: Faculty of Saint and Technology UIN Alauddin Makassar. Undergraduate Thesis. 2017.

[5] I. Dinata and W. Sunanda, "Implementation of Wireless Monitoring". Nas. Tech. Electro. Vol. 4, No. 1, pp. 83-88. 2015.

[6] Muthia, Reza, Nurhalim and Dian Yayan Sukma, "Saving Household Electricity Consumption with the Implementation of Peak Clipping and Strategic Conservation in Pekanbaru City". Journal of JOM Fakultas Teknik. Vol. 3. No. 1. 2016.

[7] R. Permana, Rumani, U. Sunarya, "Design ofInternet Of Things-Based Smarthome Security and Control Systems", eProceeding of Engineering: Vol. 4 ED-. pp 4015. 2017.

[8] Setiawan, Evan Taruna, "ArduinoMicrocontroller-Based Home Light Control Using Android Smartphone". TI-Atma STMIK Atma Luhur Pangkal pinang: pp. 1-8. 2010.

[9] Suryaningsih, Sri, Sahrul Hidayat and Faisal Abid, "Design a Internet-Based Household Electrical Energy Monitoring Device". Volume V. Department of Physics, Faculty of Mathematics and Natural Sciences Universitas Padjadjaran. 2016.

[10] Wahyudin, "Home Security Systems With Monitoring Using Cellular Phone Networks", Computer Engineering Study Program, University of Indonesia. 2015.

[11] Zulpa, A., "Prorotype Monitoring of Load and Cost Measurement of Electrical Impact with ArduinoMikrokontroller on Web-Based Pay Customers". Jakarta: faculty of Science and Technology of Syarif $\begin{array}{llll}\text { Hidayahtullah } & \text { State } & \text { University. }\end{array}$ 